\title{
BUILDING ECO-THEOLOGICAL AND BIO-CENTRIC APPROACH TO ENVIRONMENTAL ETHICS: John B. Cobb's Perspective
}

\author{
Md. Abu Sayem \\ University of Dhaka, Bangladesh \\ E-mail: sayem@du.ac.bd
}

\begin{abstract}
This paper discusses John B. Cobb's interpretation of Christian ecological moral foundation based on his "process theological" understanding as well as his critics to traditional Christian view of human supremacy over non-human creatures. It aims to explore Cobb's ecotheological understanding based on bio-centric environmental approach and explore why his eco-theological thought becomes significant for the ongoing discourses on environmental ethics, especially from religious perspectives. This research also describes how Cobb's idea could be working for sustainability of environment. In so doing, this paper enriches the current discussions on environmental ethics from Christian eco-theological perspective.
\end{abstract}

Keywords: Ecology; ethics; human supremacy; nature; stewardship.

Article history: Received: 11 August 2020; Revised: 24 September 2020; Accapted: 16 November 2020; Available online: 01 March 2021

\section{How to cite this article:}

Sayem, Md. Abu. "Building Eco-Theological and Bio-Centric Approach to Environmental Ethics: John B. Cobb's Perspective". Religió: Jurnal Studi Agama-agama 11, no. 1 (2021): 23-43. https://doi.org/10.15642/religio.v11i1.1681 


\section{Introduction}

John B. Cobb, Jr. (1925-present) ${ }^{1}$ is frequently cited as a twentieth century influential theologian in North America. He started his works in the study of "process theology" and eco-theology. He attempts studied ecological problems and exposed his own comprehensive understanding on the issue.

Meanwhile, scholars like Saderis and Jenkins are also considered as the prominent figures in the recent discussions on religious ethics of the environment. Saderis connects the evolutionary theory of Darwin in order to strong human-nature relationship by arguing that environmental ethics comes from a fundamental interdependence of all life. ${ }^{2}$ She criticizes that Cobb could not distinguish between the value of wild and domestic animals. In one place, she considers Cobb's eco-theological approach anthropocentric, ${ }^{3}$ but in another place, he states it as theocentric. ${ }^{4}$ In both places, she fails to provide sufficient arguments to prove her statements.

Intrinsically both approaches are mutually opposite to one another, because anthropocentric assumes that human is the centre of everything while theocentric believes that God is the centre of everything. Nobody can be a supporter of these two approaches at the same time. Such inconsistence implies Saderis' self-contradiction to argumentation and her misunderstanding of Cobb's biospheric vision of ecological equilibrium. Perhaps, this deficiency comes from her insufficient consultancy with Cobb's works. She confesses that she could not read Cobb's other works on environmental issues ${ }^{5}$ and only reads The Liberation of Life co-authored by Cobb and Birch.

Jenkins' approach focuses on prophetic pragmatism as well as religious ethics. For Jenkins, religious ethics is vulnerable due to its emphasis on belief system more than its practice. ${ }^{6}$ He criticizes religious ethicists for not focusing on the practical importance of

\footnotetext{
${ }^{1}$ For details, see John B. Cobb, Jr., Theological Reminiscences (Claremont, California: Process Century Press, 2014). For a theological biography of Cobb, see David Ray Griffin and Joseph C. Hough, Theology and the University: Essays in honor of John B. Cobb (Albany: State University of New York, 1991).

${ }^{2}$ Lisa H. Saderis, Environmental Ethics, Ecological Theology and Natural Selection: Suffering and Responsibility (New York: Columbia University Press, 2003).

3 Ibid., 206.

4 Ibid., 207.

${ }^{5}$ Ibid., 92.

${ }^{6}$ Willis J. Jenkins, The Future of Ethics: Sustainability, Social Justice, and Religious Pattern (Washington D.C.: Georgetown University Press, 2013).
} 
religious beliefs in connection with environmental issues. By the term of "prophetic pragmatism", Jenkins suggests a "moral storm" among practitioners of religions to address climate change. In reducing ecological problems, his emphasis on adapting moral learning with the present situation is substantial. Though Jenkins appreciates Cobb's criticism of modern economic theories and activities, he fails to grasp Cobb's biospheric vision in a holistic approach.

Both Saderis and Jenkins address the present environmental issues in connection with religious moral and environmental ethics by focusing on comprehensive naturalized-ethics and theocentric or prophetic pragmatism. Although both scholars have enriched the present discussions on eco-theological ethics from their own understandings, they cannot expose the present environmental issues by reinterpreting religious moral foundations as Cobb has done. To some points, they misunderstood Cobb's ecological model of life and development because of their insufficient consultancy of Cobb's ideas.

In spite of their negligence to Cobb's biospheric vision, Cobb's eco-theological understanding remains significant in dealing with the unprecedented ecological issues. The way Cobb connects the concept of life with God, human and nature, is barely grasped in the recent scholarships of religion based on environmental ethics. Cobb's lifebased formula of sustainable economic activities can be considered as an alternative to the modern economic theories and selfish economic functions. If Cobb's ecological model of life and development is accepted by policy makers for implementation, there will be a dramatic improvement in terms of ecological sustainability. This paper attempts to describe Cobb's Christian eco-theological understanding and look at this idea from the biocentric approach to the environmental ethics.

\section{Cobb and Environmental Issues}

Since 1969, Cobb has been thinking and working on environmental issues. ${ }^{7}$ The two readings, Paul Ehrlich's The Population $B_{o m b} b^{8}$ and Lynn White's essay "The Historical Roots of the

7 John B. Cobb, Jr., Sustainability: Economics, Ecology and Justic (Wipf and Stock Publishers, 1992), 1; John B. Cobb, Jr., Sustaining the Common Good: A Christian Perspective on the Global Economy (Cleveland, Ohio: The Pilgrim Press, 1994), vii.

8 Paul Ehrlich, The Population Bomb (New York: Ballantine Books,1968). 
Environmental Crisis" have inspired him to view an environmental degradation. White's thesis makes Christian faith responsible for anthropocentric view of nature ${ }^{10}$ that has been carrying over the centuries by human beings to exploit nature. ${ }^{11}$ In White's view, Christianity has worked as a historical root for the present environmental crisis. ${ }^{12}$ Like many other Christian theologians, it was hard for Cobb to accept White's argument that Christian tradition worked as a historical root for the environmental crisis ${ }^{13}$. So, he starts to read and finds some consistencies in White's argument. He persists that Christian theologians had interpreted biblical description of human domination in a mistaken way and eventually builds a participatory view of the environment by focusing that the Bible does not mention only the human but also deals with all creatures. $\mathrm{He}$ argues that it was not the mistake of the Bible: it was misinterpretation of Christian theologians on human-centric approach. ${ }^{14}$

Cobb states that "Christianity was certainly not the cause of the environmental crisis", ${ }^{15}$ rather it was mainly caused by modern science and technology. ${ }^{16}$ Partially Cobb supports White's argument ${ }^{17}$ in this

9 Lynn White Jr., "The Historical Roots of Our Ecologic Crisis," Science 155, no. 3767 (1967): 1203-1207.

${ }^{10}$ Lynn White categorically states, "(E)specially in its Western form, Christianity is the most anthropocentric religion the World has seen." Read White, "Historical Roots of Our Ecologic Crisis", 1205.

${ }^{11}$ J. Soneson, “Doing Public Theology: John B. Cobb, Jr.'s Reconstruction of the Concept of "World" and "God" in the context of the Environmental Crisis", American Journal of Theology \& Philosophy 15, no. 2 (1994): 154-155.

12 Andrew Brennan and Y.S. Lo explain White's arguments further: “(W1)Christianity leads to anthropocentrism, (W2)-Anthropocentrism is very harmful to the environment, (W3)-Hence, Christianity is the intellectual origin of environmental crisis." See Andrew Brennan and Y.S. Lo, Understanding Environmental Philosophy (Durham: Acumen, 2010), 165.

13 For many Christians, White's argument is controversial. They blame White for misunderstanding the creation story of the Bible. They argue that the same Bible assigns stewardship for humans to take care of God's creature. (Soneson, "Doing Public Theology", 155). It is true that White overlooks the stewardship in his thesis.

14 Cobb, Sustainability, 93.

15 Cobb, Sustainability, 2.

${ }^{16}$ For Cobb, technology alone has changed the world, and it is just used as a means of science. In his view, both science and technology are equally responsible for the degradation of planetary environment whereas he states: “... the present global crisis has emerged from the modern wedding of science and technology. Hence science shares with technology in responsibility for the threatening ecological 
way that as a dominant faith tradition in the west, Christian tradition has encouraged human-centric attitude to exploit the planetary environment. ${ }^{18} \mathrm{He}$ criticizes the role of Church and Christian theologians in supporting the so-called human domination over the natural world in the name of human supremacy. ${ }^{19}$

He describes how the planetary environment was degraded throughout the periods, and it started before the advent of human beings on earth. Natural events like meteors, volcanic eruptions, snow streams, floods, earth quakes, and firing were the major causes of environmental degradation before the existence of human beings. With the advent of human beings, the environmental degradation is more rapidly growing because of their activities of hunting and collecting. Systematic degradation happens through domesticating animals and plants during pastoral and agricultural life styles of human beings. The growth of human civilization has accelerated this degradation. The modern science and technology, with the dominant philosophical idea of human domination on the natural world, have vehemently contributed to this continuation of environmental degradation. ${ }^{20}$ Thus, the environment has been degrading with "mechanistic assumption about nature, human greed, concern for economic survival, chronic lack of foresight, social arrogance, and so on". ${ }^{21}$

According to Cobb, the planetary environment degrades in two ways: natural and human made. As natural causes are mostly beyond human control, it is difficult to take necessary actions to mitigate environmental degradation. He observes that after each natural cause the environment could enrich itself by its self-sustaining ecological system. Natural causes of environmental destruction do not continue while human-made causes of environmental degradation continue,

disaster." John B. Cobb, Jr., Is It Too Late? A Theology of Ecology (Texas: Environmental Ethics Book, 1972), 33.

${ }^{17}$ Cobb, Is It Too Late? 33-35.

${ }_{18}$ Cobb, Is It Too Late? 33-35; Cobb, Sustainability, 2.

19 As Cobb states: "Christianity teaches that (hu)man alone is made in the image of God and that God has established him as lord over all other creatures. It sometimes so accentuates man's supreme and unique importance that all other things become mere means to his ends. This tendency has dominated Western Christendom." Cobb, Is It Too Late?, 117.

${ }^{20}$ Cobb, Sustaining the Common Good, 1-3.

21 Soneson, "Doing Public Theology", 155. 
and that is why it is very dangerous for environmental sustainability. Cobb argues, human beings should be very cautious about the degradation that is caused by their own activities. For Cobb, as the present environmental crisis is mainly created by human behaviours and activities, it is the most urgent responsibility of human beings to work for environmental sustainability. Cobb does not focus on who are responsible or what is more responsible for the environmental problems $^{22}$ rather he attempts to present frameworks ${ }^{23}$ to solve and reverse these problems.

\section{Using Process Philosophy in Theological Understanding of Nature}

In many ways, Cobb was influenced by the "process philosophy"24 of Alfred North Whitehead (1861-1947). Process philosophy relates metaphysical reality with continuous changes and growth. It is argued that everything needs a creative process for its growth and changes. Whitehead sees, in previous times human understanding of science, ethics and religion was influenced by the worldview of a community, while in the modern time everything is influenced by the Western science. This dimension does not seem to him as a holistic approach in human thought; that is why he develops a holistic thought through "process philosophy" by articulating religion, ethics, cultural norms, and traditional values. In pursuit of a comprehensive cosmic view, Whitehead develops his process philosophy in a new dimension.

22 Read Cobb, Is It Too Late?, 13-17; Cobb, Sustainability, 127-130.

${ }^{23}$ For example, With Charles Birch, Cobb co-authors The Liberation of Life: From the Cell to the Community in 1982, where both scholars have presented a biospheric vision to address the present environmental issues. Similarly, Cobb co-authors For the Common Good: Redirecting the Economy Toward Community, the Environment, and a Sustainable Future with Herman E. Day (1989 / 1994), where both scholars emphasize bioregionalism to reduce the present environmental problems by reforming modern economic theories and activities. In Is It Too Late? Cobb talks about ecological model of life and development to address the current ecological crisis.

24 The term "process philosophy" is primarily related with the philosophical thought and works of Alfred North Whitehead (1861-1947) and Charles Hartshorne (1899-2000), albeit its historical roots are found in ancient periods. It was popularized by Chicago school in the middle of twentieth century. Process philosophy first avoids the subjectivism and then attempts to reconcile the various human intuitions into a holistic approach. In so doing, it aims to develop a neoclassical realism. For details, see http://www.iep.utm.edu/processp/. 
In Whitehead's view, the natural world has its own intrinsic value. Every component in the environment is real, and they are participating with humans in their own ways. For Whitehead, all biotic and abiotic organisms in the natural environment are interrelated and interconnected. Furthermore, he criticizes those who deny this reality. In his view, there are two evils: one is to ignore the true relationship of all organisms with the environment, and other is to deny their intrinsic value. Whitehead sees the entire universe as the vast ecological system. ${ }^{25}$

Being deeply reflected by Whitehead's philosophical thought, Cobb applies some of these ideas in Christian views of nature. ${ }^{26}$ Eventually Cobb has transformed Whitehead's process philosophy into theological discourse on the environment which is known as "process theology". ${ }^{27} \mathrm{He}$ uses process theology in shaping new Christian perspective in order to reverse destructive practices supported by the dominant theology in the past. Cobb sees creation as a process coming out from a dynamic process of formation, growth and changes. Everything comes from nature and returns to nature, following the process. Nothing happens in the universe but follows the process. Cobb states God as the creative process ${ }^{28}$ in the sense that God is the creator of the process. The process, in the views of many scholars, is called the natural laws. Cobb prefers to call it nature. So, nature is sacred.

Such knowledge of nature has helped Cobb to understand ecology. As a natural system, ecology refers to the relationship and interconnectedness of biotic organisms with the environment. In the natural world, everything is interrelating and interacting with one another. At the same time, they are also competing within the same group and with other groups for their growth and existence. Interdependence and competition are necessary for ecological system. For Cobb, as a part of nature human beings are bound to respect this

\footnotetext{
${ }^{25}$ Cobb, Is It Too Late?, 112-113.

26 B. McCall, A Christian Natural Theology, $2^{\text {nd }}$ ed. by John B. Cobb, Heythrop Journal, 49(4), (2008): 711.

27 In process theology, Cobb uses process thought. In process thought, dualism of mind and matter are rejected. Process thought does not support the argument that "each thing exists in a certain independence of everything else", rather it argues that "each event is constituted largely by its relations with other events." Cobb, Sustainability, 2-3.

${ }^{28}$ Cobb, Is It Too Late?, 125.
} 
wonderful system of the natural world. Human beings are included in this natural process; so, violating this system is betraying themselves. Cobb shows that nowhere in the biblical description, this natural system is considered valueless. He criticizes those who ignore the value of ecology. After rejecting the traditional Christian views of radical anthropocentricism, he works on the rights and values of ecology from theological point of view.

\section{Christian Eco-theological View}

Cobb is a critic of traditional Christian view. In reference to the creation story of the Bible, traditional Christian theologians and scholars argue that human beings are told by God to subdue over the natural world. ${ }^{29}$ As human beings are ordered to get victory over others, human beings are superior and others are inferior to them. ${ }^{30}$ By the biblical narration it is also argued that other biotic organisms have instrumental values not intrinsic values, so these are not considered as valuable things. For Cobb, this approach of Christian faith gave a limitless license to the hands of human over the centuries to exploit the natural world. Cobb argues that the concerning verse of the Bible regarding human domination over nature was misinterpreted by Christian theologians over the periods. ${ }^{31}$ From the same biblical sources, Cobb shows that it is human responsibility to take care of God's creatures not in the sense that they are beneficiary to them. ${ }^{32}$ It is true that humans are created in the image of God (Gen. 1: 27) which is a sign of human supremacy over other creatures

\footnotetext{
29 The Bible states: "So God created mankind in his own image, in the image of God he created them; male and female he created them". God blessed them and said to them, "Be fruitful and increase in number; fill the earth and subdue it. Rule over the fish in the sea and the birds in the sky and over every living creature that moves on the ground." (Gen. 1: 27-28).

30 Michael S. Northcott, The Environment and Christian Ethics (Cambridge: Cambridge University Press, 1996), 125.

31 John B. Cobb, Jr., Matters of Life and Death (Westminster: John Knox Press, 1991), 27; Cobb, Sustainability, 92-93; Cobb, Sustaining the Common Good, 18-19; Herman E. Daly and John B. Cobb, For the Common Good: Redirecting the Economy toward Community, the Environment, and a Sustainable Future (Boston: Beacon Press, 1994), 393.

32 There are 46 verses in the holy Bible taking about the human responsibility in taking care of the natural environment. For instance, Genesis 2: 15 states as follows: "Then the LORD God took the man and put him into the garden of Eden to cultivate it and keep it".
} 
and the Bible also tells humans to rule over others (Gen. 1: 28); but concurrently the same creation story ${ }^{33}$ states Adam as worker in the (Eden) garden and care taker of it (Gen. 2:15). In this relation, human is placed in the garden, i.e. the world along with others. ${ }^{34}$ It means that human special status is granted for protecting the natural world not to exploit it.

Cobb argues that before creation of human beings, God creates other creatures that is good in the eye of God. ${ }^{35}$ After the creation of human beings the whole creation was very good in the sight of God. ${ }^{36}$ It does indicate that the other creatures have intrinsic value and their values are not dependant only on human relation. ${ }^{37}$ Cobb argues, as they are created by God, they have their own value and this value is derived from their creator. All creatures of God are valuable in the sight of God. ${ }^{38}$ According to this argument, human's co-creaturehood lies in all creatures of God and human is not alien to them or the other way around. Jesus's concern about the value of sparrows implies to the intrinsic value of the other animals. "Behold the lilies of the field" (Matthew 6:28) indicates the intrinsic value of the plants. Paul's redemption ${ }^{40}$ theory includes the whole creation. In the ark of Noah, other creatures are also protected in the light of God's command. ${ }^{41}$ After the flood, God made a covenant with Noah that included the whole animal world. ${ }^{42}$

In the scriptural description of the Bible, humans are always seen within the natural world. No event of the creation stories suggests that only humans have values and other creatures have none. There is no scope to see dualism between humanity and nature.

\footnotetext{
33 It is further interpreted by Sittler whom Santmire considers as a pioneering theologian of nature. Read H. Paul Santmire, The Travail of Nature: The Ambiguous Ecological Promise of Christian Theology (Philadelphia: Fortress Press, 1985); Steven Bouma-Prediger and Peter Bakken, Evocations of Grace: The Writings of Joseph Sittler on Ecology, Theology, and Ethics (Michigan; Cambridge: William B. Eerdmans Publishing Company, 2000), 232.

${ }^{34}$ Bouma-Prediger and Bakken, Evocations of Grace, 204.

35 Cobb, Sustaining the Common Good, 18.

${ }^{36}$ Cobb, Matters of Life and Death, 27.

${ }^{37}$ Cobb, Sustaining the Common Good, 18.

38 Cobb, Is It Too Late? 117.

${ }^{39}$ Cobb, Sustaining the Common Good, 18.

${ }^{40}$ Bouma-Prediger and Bakken, Evocations of Grace, 177.

${ }^{41}$ Cobb, Matters of Life and Death, 23-24.

42 Cobb, Sustaining the Common Good, 18.
} 
Unfortunately, this kind of dualism, humanity and nature, was supported by the later Christian scholars and theologians that is not, in fact, endorsed by the Bible. Cob categorically mentions, "(I)f there is a dualism there, it is between creature and creator". ${ }^{43}$ He keeps saying, "...the Bible does not support strict anthropocentrism in relation of human beings to other creatures..." ${ }^{4}$ For Cobb, "(T)he Bible calls with great consistency for theo-centrism". ${ }^{45}$ But this biblical theocentric view was later replaced by human-centric view. ${ }^{46}$

The biblical theocentric view is not kept as it was in the Bible. Over the centuries, it was misunderstood and distorted in many ways. ${ }^{47}$ First, it was interpreted in a sense of anthropocentric view. Secondly, the service of God was separated from the service of the creatures. Again, God was separated from the creatures other than human beings, and nature was considered alien to human beings. But, according to the theocentric approach, human should recognize the service of creatures as the service of God. Without serving God's creatures, God is not served. To please God does mean to serve God's creatures. So, the theocentric approach does promote "participatory inclusion", ${ }^{48}$

What is explicated here from Cobb's interpretation is that the Bible never supports this kind of anthropocentrism where everything is seen valuable only when it comes to the relationship with human beings. Rather the Bible refers to the view that all creatures are seen in relation to God, and every creation has its specific purpose designed by its creator. Nothing is valueless in the eye of God. All abiotic and biotic organisms in the natural world have their own value, i.e. their intrinsic value without the consideration of human beings. In this way, rejecting traditional anthropocentric approach (1991: 13) Cobb talks about a participatory view of nature, which has more relationship with bio-centric views of environmental ethics, though it is not exactly the bio-centric approach in the truest sense of the term.

For Cobb, though every creature has its own intrinsic value, but all values are not at the same level; there are hierarchies among

\footnotetext{
43 Cobb, Sustainability, 93.

${ }^{44}$ Ibid.

45 Ibid.

46 Ibid.

47 Ibid.

48 Ibid.
} 
values. ${ }^{49}$ He supports the biotic pyramid ${ }^{50}$ of Aldo Leopold (18871948) according to which humans have more values than any other animals, animals have more values than plants, and thus, all biotic organisms are more valuable than abiotic organisms. One organism in the environment depends on another organism for their growth and survival. As for animal case, animals like tigers and lions only eat the meat of other animals; it is not possible to keep these animals alive on grasses. Animals like cow, deer, and goat eat plants. It is not only the case of humans that they kill animals for their foods. With these arguments, Cobb advocates a healthy biotic pyramid keeping humans at the peak. ${ }^{51}$

In the ecological system, there is a cycle where it is clearly seen that every organism depends on other organisms for their survival and without this interdependency there is nothing. Everything is important and significant for other ones, and is entitled to have intrinsic value for their ends and instrumental value for others. It is equally true in regard to human beings; they have their own value as responsible part of the natural world and they have value for others. After the death, their dead bodies become the food for other organisms of the environment. Therefore, being vegetarian cannot solve the problem of animal rights in the way that animals are sacred and immoral to kill them for foods. Even Albert Schweitzer (18751965) supports killing fishes for the food of some birds. What is needed, as Cobb suggests, is the principles of justification based on compassion in taking animals as foods. ${ }^{52}$

Unnecessary, luxurious, and very comfortable way of lifestyle should not be considered in justification. Human beings are not only rational animals but also responsible ones. The rationality and responsibility should be accompanied with each action of human beings. Cobb reiterates taking reasonable and responsible changes in the present form of lifestyle to safeguard every component of the natural world. ${ }^{53}$ This responsible lifestyle is possible only when humans see themselves as a partner in the process of healing and

49 Cobb, Is It Too Late?, 53; Charles Birch and John B. Cobb, Jr., The Liberation of Life: From the Cell to the Community (Texas: Environmental Ethics Book, 1982), 205.

50 Aldo Leopold, A Sand County Almanace and Sketches Here and There (New York; Oxford: Oxford University Press, 1949), 215.

${ }^{51}$ Cobb, Is It Too Late?, 55-56.

52 Ibid.

${ }^{53}$ Cobb, Sustainability, 34. 
growth of the natural world. For Cobb, this partnership carries responsibility where mutual relationship is the main factor, and no one can show their mastery on others. ${ }^{54}$

Cobb's understanding of Christian ecological ethics, to some extent, also covers eco-centric, eco-feminism and environmental pragmatism approaches. Though Cobb's arguments for hierarchical value systems and biotic pyramid concept of Leopold have some grounds in the anthropocentric approach, he disproves the radical anthropocentric approach from the biblical sources and Christian theological teachings. Cobb is not satisfied with the traditional mainstream anthropocentric approach to environmental ethics, and he attempts reconstructing it by a participatory view of the environment.

Cobb is aware of the modern radical environmental movement like "earthism" 55 . In his work, Cobb states this movement as a challenge to "economism", 56 the way this movement reacts to the present economic system because global economic policy does not consider ecology in the economic growth. He sees, this movement gets popularity day by day, and it can contribute to shift the global economy from the present uncompromising economic growth to sustainable development. He also hopes "that today only earthism can function as a unifying centre of a healthy and desirable opposition to economism. Only it can generate the passion and energy, the level of commitment that is needed". ${ }^{7}$

Cobb is critical to the formation of this movement. He coins this movement as a scientific materialism ${ }^{58}$ arguing that this movement puts the earth in the place of God, because in it, devotion is offered to the earth in the same way to God. ${ }^{59}$ For Cobb, it is not

\footnotetext{
${ }^{54}$ Cobb, Is It Too Late?, 124.

55 Earthism refers to a kind of devotion for taking care of the earth. But it has not limited in a set of ideas for caring the earth and its all inhabitants, rather it has emerged as a religion of the earth. Read John B. Cobb, Jr., The Earthist Challenge to Economism: A Theological Critique of the World Bank (London: Macmillan Press Ltd., 1999), 168.

56 Economism refers to the reduction of all social factors to the economic expansion for the welfare of the people. No ethical issue is considered in the economic growth. Therefore, as an ideology, it is criticized by ethicists and rights movements. For Cobb, economism is so powerful that it has superseded nationalism (Cobb, Earthist Challenge to Economism, 20-25, 35).

${ }^{57}$ Cobb, Sustaining the Common Good, 40-41.

58 Cobb, Earthist Challenge to Economism, 180.

${ }^{59}$ Cobb, Sustaining the Common Good, 40.
} 
possible to consider earth in the place of God and the other way around. ${ }^{60}$ He compares earthism with idolatry ${ }^{61}$ and does not support $\mathrm{it}^{62}$. For the same reason, Cobb has a reservation to accept "the Gaia hypothesis", though he appreciates this hypothesis to some extent. ${ }^{63}$ It is better to consider the earth as living one and sacred thing; because of such thoughts people can grow their respect to the earth and tries to avoid doing something which hurts the earth. But placing earth in the place of God or worshipping earth as the ancient Greek people used to do in honour of the earth goddess "Gaia", cannot be accepted.

\section{Other Approaches of Non-Anthropocentric Environmentalists}

Providing a comprehensive picture on some influential environmental approaches beyond anthropocentrism, Cobb begins with animal rights movement, where he shows that animal-rights groups are raising their voices against abuse and misuse of animals in the name of food and scientific experiment. Their popular slogan is "(W)e should live and let (others) live". In practice, this is not possible to follow, because in the natural world it is very common that one organism is consumed by and for other organisms. It is logical to apply virtue ethics in slaughtering animals and without proper justified reasons: no animal should be killed. Human beings should be very compassion towards domesticated and wild animals.

Deep ecologists advocate profound spiritual feelings in the way that human beings should remove the categorization between living things and non-living things. They propose to forget the human identity, because this identity provides the concept of supremacy in human mind to exploit nature. Deep ecologists are criticised by social ecologists in the way that ecological crisis cannot be solved by forgetting human identity or being merged with the natural world; rather the solution lies in the changes of the organization patterns in human life. For social ecologists, the villain is capitalism; so, first fight should be against capitalism.

Alongside social ecologists, eco-feminists are also raising strong voices against human oppression, but they add that only the

\footnotetext{
${ }^{60}$ Cobb, Earthist Challenge to Economism, 179.

${ }^{61}$ Ibid., 7.

62 Cobb, Sustaining the Common Good, 40.

${ }^{63}$ Cobb, Sustainability, 103-104.
} 
organizational changes in human life is not sufficient. They advocate for the complete destruction of patriarchal social order. They argue that male domination exploits females and the nature: both are tortured by males. They relate post-patriarchal society with the ecological sustainability.

Deep ecologists, social ecologists and eco-feminists are attacked by those who advocate sustainable agriculture. They argue that deep ecologists, social ecologists and eco-feminists do not teach farmers how to produce foods in a sustainable way. They are only focusing the values of wilderness, but they forget to know that wilderness cannot feed humans. Animal rights movements also fail to provide a sustainable model for agriculture. For them, the important thing is to get back the traditional wisdom of farmers to cultivate the lands which is ignored by modern science and technology. Those who concentrate their theories and understanding for environmental sustainability attempt to identify the core problems to control environmental degradation. They argue that humans cannot wait for Marxist socialism, post-patriarchal society, profound spiritual transformation, and getting back the traditional wisdom for sustainable agriculture, in order to solve the current environmental problem. For them, the rapid environmental degradation happens by the utilization of nuclear and fossil fuels to produce energy. Here their focusing point is how to reduce their use and motivate using alternative resources to produce energy. That is why they emphasize on environment friendly energy production like solar energy, wind mills, water waves, and biogas. People who are working for green revolution are found modest in their approach. They attempt to bring all preceding environmental ethicists and environmental movements for practical work. They are not hostile to any group; rather they, with an apologetic approach to the environment, try to work from grassroots levels. Their primary program is to plant trees, discourage people to cut trees, encourage to reduce consumption of natural resources, and try to be self-responsible for saving the environment. They are mainly working as social movement for environmental protection. This movement gets popularity in Europe and in some European country, for instance in Germany, it turns into a political party. $^{64}$

${ }^{64}$ Cobb, Sustainability, 101-105. 
Cobb appreciates all these above-mentioned thoughts and activities in environmental sustainability. He states further, it is good to know that people are now conscious about the impressive problems. He is also happy to mention that currently the church has acknowledged "that human beings are not the only intrinsically valuable part of God's creation"; ${ }^{65}$ but it is not enough for Christian people. Therefore, Cobb suggests Christian church for reforming their policies. ${ }^{66}$ In his view, traditional stewardship concept and the present environmental ethics are not sufficient for taking care of God's creatures. As God's responsible creature, Christian people have many things to do for sustainable ecology, and at the same time, they must be very conscious in their thoughts and activities so that God's place is not ignored. From this urgent need, as an eco-theologian, Cobb supports a participatory approach to environmental ethics and strengths his arguments with the biblical evidence and other logical understandings. ${ }^{67}$

Though his focus is on Christian environmental moral foundation from a process theological perspective, he intends to bring all religious traditions in the discourse of ecological equilibrium. For Cobb, "it is an urgent and important task to have inter-religious dialogue on global ecological issues"; ${ }^{68}$ and for this reason, he attempts "to combine inter-religious dialogue with ecological concern." ${ }^{\prime 69}$ He suggests people not to form global ecological ethics based on all cultural and religious traditions; rather it should be through "the creative transformation of various religious and cultural traditions and the resultant transformation of the world." 70

\section{Cobb and Bio-Centric Approach to Environmental Ethics?}

Environmental ethics is the application of ethical standards to the relationship between humans and non-human entities in the

\footnotetext{
${ }^{65}$ Cobb, Sustainability, 100.

${ }^{66}$ Ferre Frederick "Book Review of Sustainability: Economics, Ecology, and Justice by John B. Cobb, Jr.," Environmental Ethics 15, no. 4 (Winter 1993): 360.

${ }^{67}$ Cobb, Sustaining the Common Good, 401-404.

68 Pan Chiu Lai, "Inter-religious dialogue on ecology: A view from China", Religions 4, (2014): 92.

${ }^{69}$ Lai, "Inter-religious dialogue on ecology", 91.

70 Cobb, Earthist Challenge to Economism; Lai, "Inter-religious dialogue on ecology", 92.
} 
environment. $^{71}$ It is primarily divided into two approaches: anthropocentric and non-anthropocentric. ${ }^{72}$ While talking about the environment, Cobb considers the whole of both: his eco-theological understanding seemingly has a relation with some of those approaches. ${ }^{73}$ Cobb is not satisfied with the present form of environmental ethics, because it is insufficient to address the issue. For him, the current environmental ethics fails to grow a strong feeling for the natural world and cannot create inner consciousness in human mind. Furthermore, he argues, without cooperation from religions, such spiritual feelings and inner consciousness for the environment are not possible to be grown.

Cobb attempts to divert human attitude first toward nature and convince them for conducting a life-style compatible with ecological sustainability. In this regard, he looks at religions as a positive force to implement the goal. Cobb tries to reinterpret Christian teachings to form a new Christianity. ${ }^{74}$ If we assess his eco-theological thought in light of value approaches of the environmental ethics, we should say that his eco-theological understanding comparatively corresponds to a bio-centric value approach more than other value approaches of environmental ethics. Northcott notes that Cobb's approach to environmental ethics is between human-centric and eco-centric perspectives: ${ }^{75}$ it is not completely a bio-centric.

This "process-theological approach" to environmental ethics is criticized by Palmer. He argues that in Cobb's process-theology there are double claims to human superiority: one is in hierarchy of beings and other is in producing more values than other species. ${ }^{76}$ Processapproach is not free from a humanizing aspect. Eventually it differentiates human beings from other living things. Its special

\footnotetext{
${ }^{71}$ M.A. Dombayci, "Teaching of Environmental Ethics: Caring Thinking”, Journal of Environmental Protection and Ecology 15, no. 3A (2014): 1404-1421.

${ }^{72}$ Kees Vromans (Ed.), Environmental Ethics: An Introduction and Learning Guide (Sheffield: Greenleaf Publishing Ltd, 2012), 59.

73 For a brief note, see Md. Abu Sayem, "Islamic Teaching and Practice of Environmental Ethics in Bangladesh: A Case Study", Quest: Studies on Religion and Cultures in Asia 3, (2018): 1-2.

${ }^{74}$ Cobb, Is It Too Late? 55-56; Cobb, Sustainability, 7.

75 Michael S. Northcott, The Environment and Christian Ethics (Cambridge: Cambridge University Press, 1996), 161.

${ }^{76}$ Clare Palmer, Environmental Ethics and Process Thinking (Oxford: Clarendon Press, 1998), 93.
} 
characteristics lie in an anthropomorphic interpretation of the universe and these features seem problematic in building environmental ethics. Because of these limitations, Palmer considers Cobb's process-theology as an unsatisfactory intellectual alternative to environmental ethics. Palmer notes that many biologists may have difficulties to understand Cobb's understanding "grades of being". ${ }^{77}$ Cobb states that the human community is the same sort of being as a cell but in Hartshorne's view human community is a quasi-organism, it is not a true organism such as the cell. ${ }^{78}$ In Cobb's understanding of life, there is still negligence to the significant functions of nonsentient entities in the environment. ${ }^{79}$ In addition, Clare sees that Cobb is more concern for living organism albeit he speaks for the comfort of non-conscious things. ${ }^{80}$ For this reason, Trickett lightly criticizes Cobb for overlooking this issue. ${ }^{81}$ From ecological perspective, the non-sentient entities cannot be denied, and this truth is also recognized by Cobb when he discusses the definition of ecology. ${ }^{82}$

Though Cobb recognizes the hierarchy of value and biopyramid, ${ }^{83}$ which implies the superior position of humans over others, he does not deny intrinsic value of other non-human entities of the environment; rather with the biblical interpretations (Gen. 2: 15) along with other scientific evidences, he shows that other non-human beings have inherent value. ${ }^{84}$ Similarly, he criticizes Christian scholars and theologians for misinterpreting the biblical verse (Gen. 1:28) to disprove intrinsic value of other entities. ${ }^{85} \mathrm{He}$ suggests interpreting Gen. 1: 28 with Gen. 2: 15 for having a clearer comprehensive understanding about the relationship between humans and other nonhuman components of the natural world. He argues, as God's creation, everything has its own value ${ }^{86}$ but all values are not equal. ${ }^{87}$

\footnotetext{
77 Palmer, Environmental Ethics, 93.

78 Ibid., 94.

79 David G. Trickett, (Book Review of The Liberation of Life: From the Cell to the Community by Charles Birch and John B. Cobb), Environmental Ethics 5, no. 1 (1983): 93.

80 Palmer, Environmental Etbics, 94.

81 Trickett, (Book Review of The Liberation of Life), 93.

82 Cobb, Is It Too Late?, 28.

${ }^{83}$ Cobb, Is It Too Late?, 53; Birch and Cobb, The Liberation of Life, 205.

${ }^{84} \mathrm{Cobb}$, Is It Too Late? 117.

${ }^{85}$ Cobb, Sustainability, 92-94.

${ }^{86}$ Cobb, Is It Too Late?, 117.
} 
$\mathrm{He}$ is convinced that the Bible never recognizes an extreme anthropocentric value approach, ${ }^{88}$ though humans are given special dignity over other creatures. For him, if there is any value centric approach in the Bible, it is, of course, God-centric, not anthropocentric.

In Cobb's view, it is a fault of Christian scholars and theologians that they have transformed this theocentric approach into anthropocentric approach over the centuries. ${ }^{89}$ In this way, Cobb reinterprets Christianity from an ecological perspective. However, when Cobb talks about the intrinsic value of all biotic organisms, it relates with bio-centric approach: ${ }^{90}$ when he talks about relationship of all living forms in themselves and concurrently with non-living components of the environment, it also deals with eco-centric approach; and when he talks about hierarchy of values and biotic pyramid it may be misunderstood as an anthropocentric approach by some environmentalists.

Relating to a bio-centric value approach, Cobb's eco-theological understanding is his own value approach to environmental ethics by focusing a participatory relationship of all living forms on earth. Though Cobb appreciates "earthism" and Gaia hypothesis to some extent as an opposing movement to "economism", he is very critical of these two new theories and approaches because of their possibility to replace God. ${ }^{11}$ For Cobb, as God's responsible creature, humans should not accept anything in which God's place is neglected. He does not like to see unexpected debates and unnecessary disputes between and among the existing environmental movements: deep ecologists, social ecologists, eco-feminists, sustainable agriculturalists, and green movements. He advocates a combined working force between and among them to halt the present unprecedented ecological crisis. He does not want to rely only on traditional stewardship concept and the present environmental ethics; for him,

\footnotetext{
${ }^{87}$ Cobb, Is It Too Late?, 53; Birch and Cobb, The Liberation of Life, 205.

${ }^{88}$ Cobb, Sustainability, 93.

${ }^{89}$ Cobb, Sustainability, 93.

90 Read Thomas Michael Power, "Book Review of For the Common Good: Redirecting the Economy Toward Community, Environment, and Sustainable Future by Herman E. Daly and John B. Cobb, Jr.," Environmental Ethics 15, no. 1 (1993): 86-90; David A. Pailin, "Book Review of Process Theology as Political Theology, by John B. Cobb, Jr.," Religious Studies 19, no. 3 (September 1983): 420.

${ }^{91}$ Cobb, Sustaining the Common Good, 40; Cobb, Earthist Challenge to Economism, 7, 179.
} 
both are insufficient to care of the environment. ${ }^{92}$ He has developed certain frameworks like ecological asceticism, ${ }^{93}$ ecological model of life $^{94}$ and ecological model of development ${ }^{95}$ in order to address the present environmental crisis. In sort, Cobb's eco-theological approach seems inclusive to certain points, critical to some extent, and practical in terms of implementation.

\section{Conclusion}

Cobb's Christian ecological ethics seems realistic and pragmatic in the discourses of environmental ethics. ${ }^{96}$ In spite of similarities with a biocentric approach Cobb's eco-theological ethical understanding implies a distinct and unique initiative to address the present environmental issues. Northcott has rightly mentioned, "Cobb's approach is a dramatic departure from traditional Christian theism, and has much in common with the holistic, mystical and ecocentric deep ecologies." ${ }^{\text {"7 }}$ However, Cobb has not confined his discussion only in interpreting the biblical verses correlating with physical environment of traditional understanding rather integrated it with the modern knowledge of biological sciences. By relating faith tradition with philosophy and science, he presents a comprehensive understanding of life in terms of ecological sustainability. Cobb is credited with the attempt of reconstructing Christian views of the environment in the present discourses of environmental ethics.

\section{References}

Birch, Charles and John B. Cobb, Jr. The Liberation of Life: From the Cell to the Community. Texas: Environmental Ethics Book, 1982.

Bouma-Prediger, Steven and Peter Bakken. Evocations of Grace: The Writings of Joseph Sittler on Ecology, Theology, and Ethics. Michigan; Cambridge: William B. Eerdmans Publishing Company, 2000.

Brennan, Andrew and Y.S. Lo. Understanding Environmental Philosophy. Durham: Acumen, 2010.

Cobb, John B., Jr. Is It Too Late? A Theology of Ecology. Texas: Environmental Ethics Book, 1972.

\footnotetext{
${ }^{92}$ Cobb, Is It Too Late?, 124; Birch and Cobb, Liberation of Life, 150.

${ }_{93}$ Cobb, Is It Too Late?, 58, 63.

${ }^{94}$ Birch and Cobb, Liberation of Life, 122-123.

${ }^{5}$ Cobb, Sustaining the Common Good, viii; Daly and Cobb, For the Common Good, 229.

96 Soneson, "Doing Public Theology", 157.

${ }^{97}$ Northcott, Environment and Christian Ethics, 149.
} 
----. Matters of Life and Death. Westminster: John Knox Press, 1991.

----. Sustainability: Economics, Ecology and Justice. Wipf and Stock Publishers, 1992.

-----. Sustaining the Common Good: A Christian Perspective on the Global Economy. Cleveland, Ohio: The Pilgrim Press, 1994.

----. The Earthist Challenge to Economism: A Theological Critique of the World Bank. London: Macmillan Press Ltd., 1999.

-----. Theological Reminiscences. Claremont, California: Process Century Press, 2014.

Daly, Herman E. and John B. Cobb, Jr. For the Common Good: Redirecting the Economy Toward Community, the Environment, and a Sustainable Future. Boston: Beacon Press, 1994.

M. A. Dombayci. "Teaching of Environmental Ethics: Caring Thinking". Journal of Environmental Protection and Ecology, Vol. 15, no. 3A (2014): 1404-1421.

Griffin, David Ray and Joseph C. Hough. Theology and the University: Essays in honor of John B. Cobb. Albany: State University of New York, 1991.

Paul Ehrlich. The Population Bomb. New York: Ballantine Books, 1968.

Pope Francis, Encyclical Letter "Laudato Si" of the Holy Father Francis. $1^{\text {st }}$ Ed. (Vatican City): (Vatican Web Site), 2015.

Hodder and Stoughton. Holy Bible (New International Version Compact Edition). London; Sydney; Auckland: Hodder \& Stoughton, 2002.

Jenkins, Willis. "Islamic Law and Environmental Ethics: How Jurisprudence (Usul al-Fiqh) mobilizes practical Reform". Worldviews: Environment, Culture, Religion, Vol. 10, no. (1) (2006): 338-364.

-----. "Religion and Ecology: A Review Essay on the Field." Journal of the American Academy of Religion Vol. 77, no. 1 (2009): 187-197.

-----. The Future of Ethics: Sustainability, Social Justice, and Religious Pattern. Washington D.C.: Georgetown University Press, 2013.

Jenkins, Willis J. "After Lynn White: Religious Ethics and Environmental Problems." The Journal of Religious Ethics Vol. 37, no. 2 (2009): 283-309.

Jenkins, Willis J. and C. K. Chapple. Religion and Environment, Annual Review of Environment and Resources Vol. 36, (2011): 441463.

Leopold, Aldo. A Sand County Almanace and Sketches Here and There (Special Commemorative Edition). New York; Oxford: Oxford University Press, 1949. 
McCall, B. A Christian Natural Theology, $2^{\text {nd }}$ ed. by John B. Cobb. Heythrop Journal 49, no. 4 (2008): 711-712.

Northcott, Michael S. The Environment and Christian Ethics. Cambridge: Cambridge University Press, 1996.

Lai, Pan Chiu. "Inter-religious dialogue on ecology: A view from China". Religions 4, (2014): 82-97.

Pailin, David A. "Book Review of Process Theology as Political Theology, by John B. Cobb, Jr." Religious Studies 19, no. 3, (September 1983): 419-421.

Palmer, Clare. Environmental Ethics and Process Thinking. Oxford: Clarendon Press, 1998.

Paul, Pope John II. "The Ecological Crisis: A Common Responsibility - Message of His Holiness Pope John Paul II for the Celebration of the World Day of Peace 1 January 1990". Vatican City; Washington, D.C.: United States Catholic Conference, 1989.

Power, Thomas Michael. (Book Review of For the Common Good: Redirecting the Economy Toward Community, Environment, and Sustainable Future by Herman E. Daly and John B. Cobb, Jr.). Environmental Ethics 15, no. 1 (1993): 85-90.

Schweitzer, Albert. Civilization and Ethics. Translated from the German by Campion, C.T. and Russell, Mrs. Charles E.B. London: Unwin Books published in association with A. \& C. Black, 1967.

Saderis, Lisa H. Environmental Ethics, Ecological Theology and Natural Selection: Suffering and Responsibility. New York: Columbia University Press, 2003.

Santmire, H. Paul. The Travail of Nature: The Ambiguous Ecological Promise of Christian Theology. Philadelphia: Fortress Press, 1985.

Sayem, Md. Abu. Religions and Environmental Sustainability: Focusing Some Practical Approaches by John B. Cobb Jr. and Seyyed Hossein Nasr. Australian Journal of Islamic Studies 6, no. 1 (2021): 65-80.

-----. Islamic Teaching and Practice of Environmental Ethics in Bangladesh: A Case Study. Quest: Studies on Religion and Cultures in Asia 3, (2018): 1-28.

Soneson, J. “Doing Public Theology: John B. Cobb, Jr.'s Reconstruction of the Concept of "World" and "God" in the 
context of the Environmental Crisis." American Journal of Theology \& Philosophy 15, 2 (1994): 153-161.

Trickett, David G. (Book Review of The Liberation of Life: From the Cell to the Community by Charles Birch and John B. Cobb). Environmental Ethics 5, no. 1 (1983): 91-93.

Vromans, Kees (Ed.). Environmental Ethics: An Introduction and Learning Guide. Sheffield: Greenleaf Publishing Ltd., 2012.

White, Lynn Jr. "The Historical Roots of Our Ecologic Crisis." Science 155, no. 3767 (1967): 1203-1207. 